\title{
HPSE2 wt Allele
}

National Cancer Institute

\section{Source}

National Cancer Institute. HPSE2 wt Allele. NCI Thesaurus. Code C91277.

Human HPSE2 wild-type allele is located within 10q23-q24 and is approximately 777 kb in length. This allele, which encodes heparanase- 2 protein, plays a role in the modulation of the structure of the extracellular matrix. 